\author{
Military Technical College \\ Kobry El-Kobbah, \\ Cairo, Egypt
}

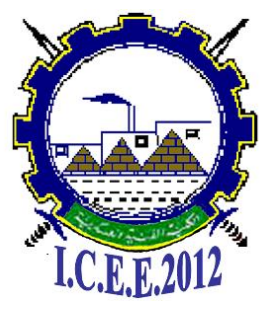

$6^{\text {th }}$ International Conference

on

Chemical \& Environmental

Engineering

29 -31 May, 2012.

\title{
MESOPOROUS METAL OXIDES BASED NANOTUBES, HOLLOW-SPHERES AND MESOCAGES FOR ENVIRONMENTAL CLEAN-UP SYSTEMS: AIR, WATER AND SOIL
}

\begin{abstract}
Professor Sherif A. El-Safty ${ }^{*}$
$\underline{\text { Abstract }}$

Environmental pollutions due to the toxic gases, elements and pathogenic speciesare a serious problem with harmful effects on plants, animals, and human health. Achieving proper designs of nanosensors for highly sensitive and selective detection and removal of extremely hazardous materials is one of the crucial issues in our laboratory. Our main interest is not only to make nanotechnological designs-based nanomaterials but also to reduce the production cost andto expand their potentialon-site and real-time measurements.El-Safty and Co-workers designed ofnanopackages-based mesocage mosaic, core/double-shell, nanosheets, hollow sphere and nanowires metal oxides for capturing and monitoring toxic agents toprotect human health and improve the environmental quality. However, we developed rapid easy-handling and cheap nanosensors for visual detection and removal of toxic metals from water and wastewater treatment systems, which are major public health challenges in worldwide (Scheme 1). Our optical mesoporous sensors show ability to create simultaneous designs for complete removal of extremely toxic metals such as $\mathrm{As}(\mathrm{V}), \mathrm{Hg}$ (II), $\mathrm{Cd}(\mathrm{II})$, $\mathrm{Pb}(\mathrm{II}), \mathrm{Cr}(\mathrm{VI}), \mathrm{Zn}(\mathrm{II})$ ions and etc.., with indoor and outdoor responses, and with revisable, selective and sensitive recognition of these toxic metals [1-10].
\end{abstract}

Toward the challenging subject of radiaoactive monitoring and separation after the recent disaster of the nuclear plants at Fukushima Diaichi, JAPAN (March, 11, 2011), El-Safty and co-workers developed simple processing and captors-based nanomaterials for separation of the radioactive of Iodine $\left({ }^{131} \mathrm{I}_{2}\right)$, strontium $\left({ }^{85} \mathrm{Sr}\right)$, cesium $\left({ }^{137} \mathrm{Cs}\right)$, cerium $\left({ }^{144} \mathrm{Ce}\right)$ and cobalt $\left({ }^{60} \mathrm{Co}\right)$ in aqueous and marine water. Our technology is not only enabled the ultra-trace concentrating collection of ${ }^{137} \mathrm{Cs}$, ${ }^{85} \mathrm{Sr}$ and ${ }^{131} \mathrm{I}_{2}$ radio-elements but also led to

\footnotetext{
* National Institute for Materials Science, 1-2-1 Sengen, Tsukuba, Ibaraki, 305-0047, Japan Graduate School for Advanced Science and Engineering,Waseda University, 3-4-1 Okubo, Shinjuku-ku, Tokyo 169-8555, Japan

E-mail: sherif@aoni.waseda.jp,

E-mail: sherif.elsafty@nims.go.jp

http://www.nims.go.jp/waseda/en/labo.html
}

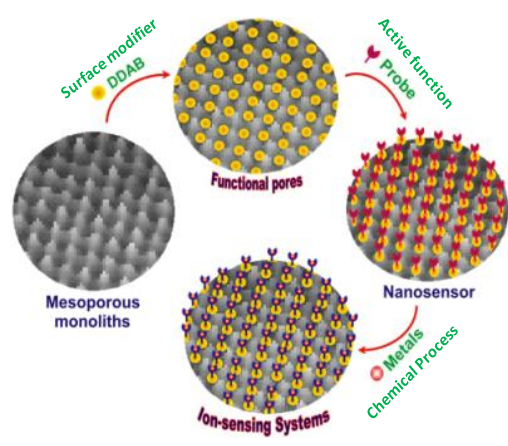

Scheme1 Design of optical nanosensor for monitoring the toxic metals from water

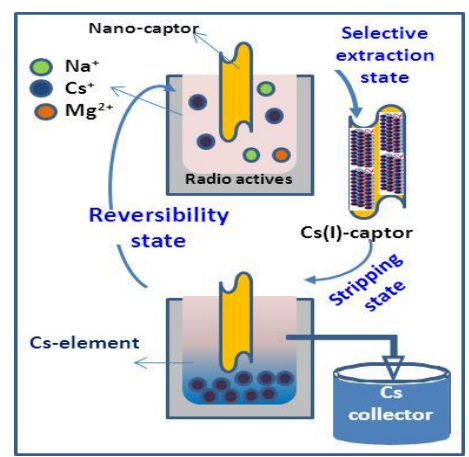

Scheme 2 Decontamination process of radioactive elements using nano-captors

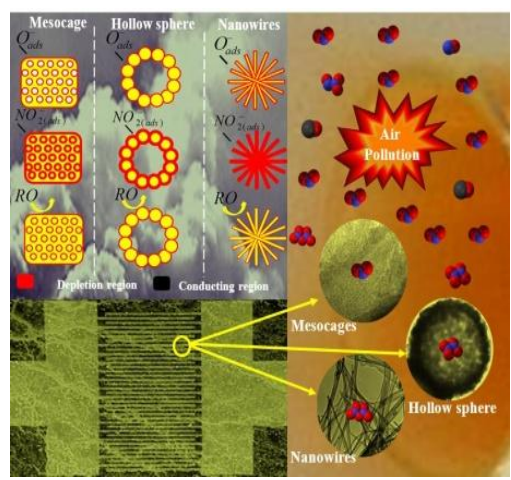

Scheme 3 Gas sensor devices based nanomaterials for detection of toxic $\mathrm{NO}_{2}$ 


\section{Military Technical College Kobry El-Kobbah, Cairo, Egypt}

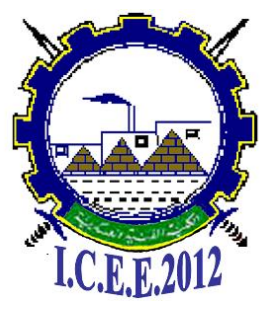

$6^{\text {th }}$ International Conference on

Chemical \& Environmental Engineering 29 -31 May, 2012.

decreasing capacity, and managing of these radioactive elements (Scheme 2). Moreover, the nanocapture material can be repeatedly recycled. Significantly, the color of the nano-capture material changes when the radio-element is adsorbed. Therefore, it is possible not only had to be captured the element effectively but also to be used to detect radioactive elements by visualization [5-8].

Recently, we have successfully fabricated nanopackage gas sensors. The patterned design based on nanosized $\mathrm{WO}_{3}, \mathrm{Co}_{2} \mathrm{O}_{3}, \mathrm{SnO}_{2}$ and $\mathrm{NiO}$ oxides enabled the detection of extremely toxic nitrogen dioxide $\left(\mathrm{NO}_{2}\right)$ and volatile organic compounds VOCs. The principal design of the nanopackages relies on the enhancement of total-volume-exposure of sensing materials to the analytic gases (Scheme 3). The key component of this design is that the gas nanosensors can offer ultra-sensitive and selective detection of nitrogen dioxide at a low level concentration among carbon monoxide, and VOCs, such as acetone, benzene, and ethanol. We expected this nanopackage sensors can revolutionize the consumer and industrial market in environmental pollution monitoring, transportation, security, defense, space missions, energy, agriculture, and medicine [9].

\section{[1] References}

[2] "Optical sensors: Toxic Sink"

http://www.nature.com/nnano/reshigh/2006/1006/full/nnano.2006.122.html, Nature Nano, 2006.

[3] S. A. El-Safty, T. Hanaoka, F. Mizukami, Adv. Mater. 2005, 17 (1), 47-53.

[4] S. A. El-Safty, T. Hanaoka, F. Mizukami, Chem. Mater. 2005. 17, 3137-3145.

[5] S. A. El-Safty, F. Mizukami, T. Hanaoka, J. Phys. Chem. B, 2005, 109, 9255-9264.

[6] S. A. El-Safty, M. Mekawy, A. Yamaguchi, A. Shahat, K. Ogawa, N. Teramae, Chem. Commun. 2010, 46, 3916-3919.

[7] S. A. El-Safty, A. Shahat, W.Warkocki, M. Ohnuma, Small, 2011, 7, 62-65.

[8] S. A. El-Safty, T. Hanaoka, F. Mizukami, Appl. Catal. B: Environ. 2008, 82, 169- 179.

[9] S. A. El-Safty, D. Prabhakaran. A. Ismail, H. Matsunaga, F. Mizukami, Adv. Funct. Mater. 2007, 17, 3731-3745.

[10] S. A. El-Safty, A. Ismail, H. Matsunaga, F. Mizukami, Chem. Eur. J.2007, 13, 9245-9255.

[11] S. A. El-Safty, T. Balaji, T. Hanaoka, H. Matsunaga, F. Mizukami, Angew.Chem. Int. Ed. 2006,45, 7202-7208. 